\title{
Adiponectin inhibits colorectal cancer cell growth through the AMPK/mTOR pathway
}

\author{
MICHIKO SUGIYAMA ${ }^{1}$, HIROKAZU TAKAHASHI ${ }^{1}$, KUNIHIRO HOSONO $^{1}$, HIROKI ENDO $^{1}$, \\ SHINGO KATO $^{1}$, KYOKO YONEDA ${ }^{1}$, YUICHI NOZAKI ${ }^{1}$, KOJI FUJITA $^{1}$, MASATO YONEDA $^{1}$, \\ KOICHIRO WADA ${ }^{2}$, HITOSHI NAKAGAMA ${ }^{3}$ and ATSUSHI NAKAJIMA ${ }^{1}$ \\ ${ }^{1}$ Division of Gastroenterology, Yokohama City University School of Medicine, 3-9 Fuku-ura, Kanazawa-ku, Yokohama; \\ ${ }^{2}$ Department of Pharmacology, Graduate School of Dentistry, Osaka University, 1-8 Yamadaoka, Suita, Osaka; \\ ${ }^{3}$ Biochemistry Division, National Cancer Center Research Institute, 1-1 Tsukiji 5-chome, Chuo-ku, Tokyo, Japan
}

Received July 2, 2008; Accepted September 25, 2008

DOI: 10.3892/ijo_00000156

\begin{abstract}
Adiponectin is a peptide hormone secreted by adipose tissue. It is a key hormone responsible for insulin sensitization, and its circulating level is inversely associated with abdominal obesity. Recent studies have shown that a reduced plasma adiponectin level is significantly correlated with the risk of various cancers. However, there are few studies regarding the association of adiponectin and colorectal cancer. To address this issue, we investigated the effect of adiponectin on colorectal cancer cells. Three colorectal cancer cell lines express both AdipoR1 and AdipoR2 receptors. MTT assay revealed that adiponectin inhibited human colorectal cancer cell growth. Furthermore, Western blot analysis revealed that adiponectin activated adenosine monophosphate-activated protein kinase (AMPK) and suppressed mammalian target of rapamycin (mTOR) pathways. Selective AMPK inhibitor compound $\mathrm{C}$ abrogated the inhibitory effect of adiponectin on cell growth. Our results clearly demonstrate the novel findings that adiponectin inhibits colorectal cancer cell growth via activation of AMPK, thereby down-regulating the mTOR pathway.
\end{abstract}

\section{Introduction}

Colorectal cancer (CRC) is one of the most common malignancies. Obesity, especially visceral obesity, has been reported to be associated with CRC $(1,2)$. Adipose tissue is not only a fat storage organ, but it secretes several bioactive

Correspondence to: Dr Atsushi Nakajima, Division of Gastroenterology, Yokohama City University School of Medicine, 3-9 Fuku-ura, Kanazawa-ku, Yokohama, Japan

E-mail: nakajima-tky@umin.ac.jp

Key words: adiponectin, colorectal cancer, cell growth, AdipoR1/ AdipoR2, adenosine monophosphate-activated protein kinase substances known as adipocytokines $(3,4)$. Adiponectin is secreted from adipocytes and is a key hormone responsible for insulin sensitization (5-12). Its plasma level is dramatically decreased in patients with obesity and type 2 diabetes mellitus (DM) $(4,5,13)$. Since both obesity and type 2 DM have been reported to be associated with an elevated risk of CRC (14), it is speculated that the plasma level of adiponectin may be related to the risk of CRC. However, several contradictory results have been reported from human clinical studies on the relationship between the plasma levels of adiponectin and the risk of CRC $(15,16)$.

It is well known that the adiponectin receptor exists in two isoforms: adiponectin receptor 1 (AdipoR1) and 2 (AdipoR2) (17). These receptors mediate cellular functions by activating intracellular signaling pathways (17). The molecular pathways downstream of AdipoRs remain to be fully elucidated, but studies in metabolically-responsive cells have shown that activation of the pleiotropic adenosine monophosphate-activated protein kinase (AMPK) is involved in the signaling cascade downstream of adiponectin receptors $(18,19)$. AMPK plays a key role in the regulation of energy homeostasis and acts as a 'metabolic sensor' to regulate adenosine triphosphate (ATP) concentrations (20). It is also associated with cell growth; phosphorylated AMPK suppresses mammalian target of rapamycin (mTOR) signaling pathway $(21,22)$. mTOR plays a central role in the regulation of cell proliferation, growth, differentiation, migration and survival (23-26), and may be abnormally regulated in tumors (23,27-29). The 70-kDa ribosomal protein S6 kinase (p70S6K) and S6 ribosomal protein (S6P) are part of the signaling cascade downstream of mTOR; they are activated via phosphorylation by mTOR $(28,30,31)$. Non-cleaved adiponectin (full-length adiponectin; f-adiponectin) and proteolytically-cleaved adiponectin containing a C-terminal globular region (globular adiponectin; g-adiponectin) were reported to have different affinities to AdipoR1 and AdipoR2 (17). In this study, we only examined the g-adiponectin because this isoform binds both receptors, while f-adiponectin has low affinity to AdipoR1 (17), and it exerts more potent effect than f-adiponectin (5). However, the expression levels of AdipoR1 and AdipoR2, the affinity of the different forms of 
adiponectin to those receptors, and the associated intracellular signaling pathways in the colorectum remain unclear. In this study, we investigated the effect of adiponectin on cell growth and the intracellular signaling pathway involved in CRC cell lines.

\section{Materials and methods}

Reagents and antibodies. Human globular adiponectin was purchased from BioVendor Laboratory Medicine Inc. (Brno, Czech Republic). Compound C was purchased from Calbiochem (La Jolla, CA) and 3-(4,5-dimethyl-thiazol-2-yl)2,5-diphenyl tetrazolium bromide (MTT) was purchased from Sigma Chemical Co. (St. Louis, MO). Anti-total and -phosphorylated (Thr172) AMPK, anti-total and -phosphorylated (Ser2448) mTOR, anti-total and -phosphorylated (Thr421/Ser424) p70S6 kinase, anti-total and -phosphorylated (Ser240/244) S6 ribosomal protein, and anti-rabbit horseradishperoxidase-conjugated $\mathrm{IgG}$ antibodies were obtained from Cell Signaling Technology, Inc. (Beverly, MA). Anti-AdipoR1 (C-14), anti-AdipoR2 (N-19), and anti-goat horseradishperoxidase-conjugated IgG antibodies were from Santa Cruz Biotechnology, Inc. (Santa Cruz, CA). Anti-glyceraldehyde3-phosphate dehydrogenase (G3PDH) antibody was from Trevigen, Inc. (Gaithersburg, MD).

Cell lines. The human colon adenocarcinoma cell lines, HT-29, Lovo, and HCT116 were used for this study. Lovo was obtained from Health Science Research Resources Bank (Osaka, Japan), while HT-29 and HCT116 were obtained from American Type Culture Collection (Manassas, VA). HCT116 and HT-29 were cultured in McCoy's 5A, and Lovo was cultured in Ham's F12, supplemented with 10\% FBS, penicillin $(100 \mathrm{U} / \mathrm{ml})$ and streptomycin $(100 \mu \mathrm{g} / \mathrm{ml})$ (all from Invitrogen, Carlsbad, CA) at $37^{\circ} \mathrm{C}$ under a humidified atmosphere of $5 \% \mathrm{CO}_{2}$.

Western blot analysis. Cultured cells treated with the test compound for indicated time periods were rinsed with phosphate-buffer saline (PBS). For obtaining the total cell extracts, cells were harvested in lysis buffer $(50 \mathrm{mM}$ Tris$\mathrm{HCl}, 100 \mathrm{mM} \mathrm{NaCl}, 5 \mathrm{mM}$ EDTA, 1\% TritonX-100) containing a cocktail of protease inhibitors (Sigma). The lysates were incubated on ice for $30 \mathrm{~min}$ and centrifuged at 15,000 rpm. Protein concentrations were determined using the Bio-Rad Protein Assay Reagent (Bio-Rad, Richmond, CA). Proteins were separated by SDS/PAGE (7.5-12.5\% gels) and transferred onto a Hybond-P PVDF membrane (Amersham Biosciences, Little Chalfont, UK). After the transfer, the membranes were blocked with Blocking One-P (Nacalai Tesque, Kyoto, Japan) and probed with the primary antibodies specified below. Horseradish-peroxidase-conjugated secondary antibodies and the ECL detection kit (Amersham Biosciences, Little Chalfont, UK) were used for the detection of specific proteins. Images were captured and analyzed by LAS-3000 imaging system (Fujifilm, Tokyo, Japan).

Cell growth assay. Cells were seeded in 96-well, flat-bottom microtiter plates at a density of $5 \times 10^{3}$ cells per well and incubated in medium containing $1 \%$ FBS. After $24 \mathrm{~h}$, the

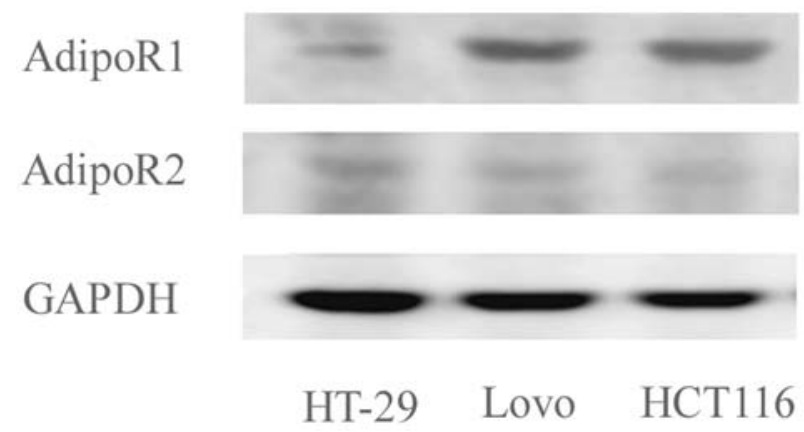

Figure 1. Expression of adiponectin receptors in colorectal cancer cells. Western blot analysis revealed that three kinds of colorectal cancer cell lines HCT116, HT-29 and Lovo cells, expressed both AdipoR1 and AdipoR2 receptors

complete medium was replaced with test medium for $24 \mathrm{~h}$ at $37^{\circ} \mathrm{C}$. After incubating the plates for an additional $4 \mathrm{~h}$ with MTT solution $(0.5 \%)$, sodium dodecylsulfate was added to a final concentration of $10 \%$ and absorbance at $595 \mathrm{~nm}$ was determined for each well using a microplate reader (Model 550; Bio-Rad). Three independent experiments were carried out for each cell line. Annexin V-FITC and PI double staining with the Annexin V-FITC apoptosis detection kit I (BectonDickinson, San Jose, CA, USA) followed by FACScan flow cytometry (Becton-Dickinson) was used to identify apoptotic cells. Cell fluorescence was measured with a FACScan flow cytometer from BD Biosciences (San Jose, CA, USA). Dual parameter cytometric data were analyzed by using CellQuest software from BD Biosciences. Apoptosis measures were performed in triplicate.

Statistical analysis. All results are expressed as mean \pm SEM. Statistical analyses were performed using Student's t-test after analysis of variance (ANOVA). The results were considered to be statistically significant at $\mathrm{p}<0.05$.

\section{Results}

Expression of adiponectin receptors on colorectal cancer cells. Western blot analysis revealed that three kinds of colorectal cancer cell lines, HCT116, HT-29 and Lovo, expressed both AdipoR1 and AdipoR2 receptors (Fig. 1). In HT-29, weak expressions of both of AdipoRs were observed. In Lovo and HCT116, strong expression of AdipoR1, and weak expression of AdipoR2 were observed.

Globular adiponectin (g-adiponectin) inhibited human colorectal cancer cell growth. To determine the effect of gadiponectin on colorectal cancer cell growth, MTT assay was performed using HCT116, HT-29 and Lovo cells. To reduce the effect of adiponectin in serum, all experiments were conducted using the culture medium containing $1 \%$ FBS. G-adiponectin significantly inhibited colorectal cancer cell growth in all examined cells in a dose-dependent manner (Fig. 2).

G-adiponectin up-regulates AMPK activity in colorectal cancer cells. The effect of g-adiponectin on the phosphorylation of 
A

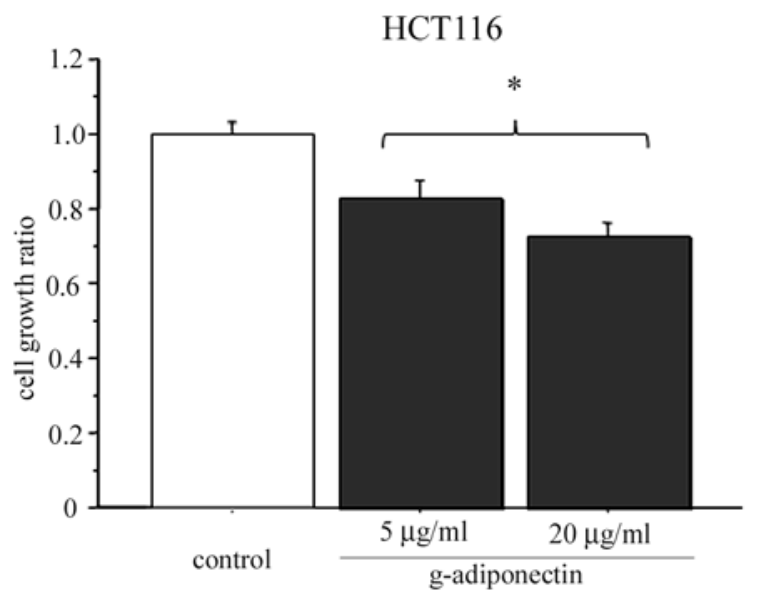

Figure 2. Globular adiponectin inhibited human colorectal cancer cell growth HCT116 (A), HT-29 (B), and Lovo (C) cells were plated onto 96-well flatbottom plates in culture medium containing $1 \%$ FBS at a density of $5 \times 10^{3}$ cells per well. After $24 \mathrm{~h}$, culture medium containing 1\% FBS and g-adiponectin ( $5 \mathrm{mg} \mathrm{ml}$ or $20 \mathrm{mg} / \mathrm{ml}$ ) was added, and incubated for $24 \mathrm{~h}$. Cell growth in each well was measured by MTT assay. Cell growth ratio (Y-axis) is represented by the ratio of treated to untreated cells via the MTT readings. Columns indicate means of three independent experiments carried out in triplicate $(n=8)$; Values are means \pm SEM. ${ }^{*} \mathrm{P}<0.05$.

AMPK and mTOR signaling pathway was examined. Western blot analysis revealed that g-adiponectin significantly phosphorylated AMPK and its effect on AMPK phosphorylation was maximal at $6 \mathrm{~h}$ after treatment (Fig. 3A). We also observed the significant phosphorylation of mTOR, p70S6K, and S6 proteins by the treatment with g-adiponectin (Fig. 3B-D). These results suggest that g-adiponectin inhibits colorectal cancer cell growth via AMPK activation and mTOR signaling pathway suppression. Selective AMPK inhibitor compound C reversed the g-adiponectin induced cell growth inhibition in HCT116 colorectal cancer cells, as detected by MTT assay (Fig. 3E). This indicates that g-adiponectin-induced cell growth inhibition is mediated by activation of AMPK.

$G$-adiponectin has no effect on apoptosis. The effect of gadiponectin on apoptosis in HCT116 and HT-29 was evaluated using annexin V-FITC and PI double staining. There was no apoptotic effect in HCT116 and HT-29 treated with $5 \mu \mathrm{g} / \mathrm{ml}$ g-adiponectin or $20 \mu \mathrm{g} / \mathrm{ml} \mathrm{g-adiponectin} \mathrm{in} \mathrm{basal} \mathrm{medium}$ containing $1 \%$ FBS (Fig. 4).

\section{Discussion}

The association of low plasma adiponectin level and cancer risk was previously reported (32-35). However, there are few studies regarding the association of adiponectin and colorectal cancer $(15,36)$. In the present study, we demonstrated both of
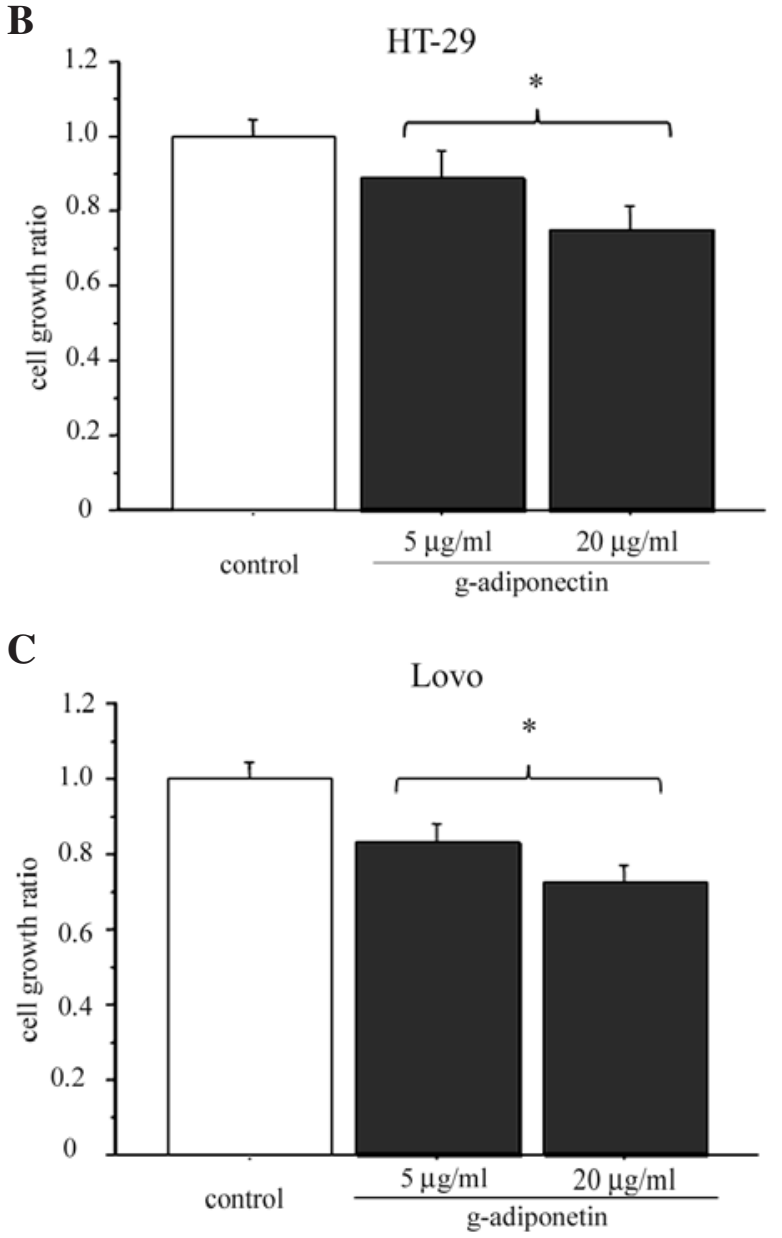

the AdipoR expression levels and g-adiponectin activation of the AMPK, resulting in the suppression of mTOR signaling pathway in colorectal cancer cell lines. Our recent study demonstrated that AdipoRs were expressed in normal colon epithelial and colorectal cancer cells in human (37). In this study, three kinds of colorectal cancer cell lines HCT116, HT-29 and Lovo cells were shown to express AdipoRs. Furthermore, we clearly demonstrated that globular adiponectin inhibited colorectal cancer cell growth and activated AMPK, while selective AMPK inhibitor compound $\mathrm{C}$ reversed the effect of g-adiponectin-induced cell growth inhibition, which indicates that g-adiponectin inhibits cell growth via regulation of AMPK. mTOR is one of the enzymes downstream of AMPK. AMPK activation acts as an inhibitor of mTOR pathway and suppresses tumor development $(38,39)$. In this study, we demonstrated that g-adiponectin suppressed the mTOR pathway following the activation of AMPK. These results suggest that g-adiponectin suppresses cancer cell growth through AMPK activation and subsequent inhibition of mTOR pathway. However, the mechanisms through which adiponectin affects cancer cells are not completely elucidated, thus there is a possibility that suppression of mTOR pathway by adiponectin is mediated through other enzymes $(40,41)$. Further studies are needed to evaluate the molecular pathways downstream of each AdipoR.

In conclusion, this study clearly demonstrates the novel findings that g-adiponectin inhibits colorectal cancer cell 
A

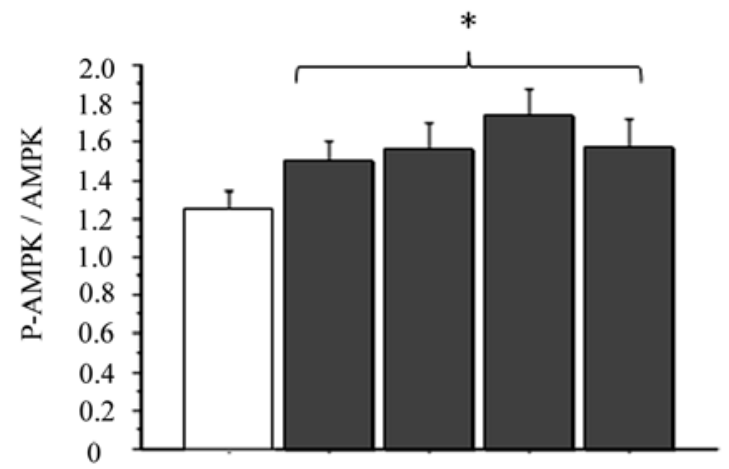

phospho-AMPK

AMPK

GAPDH

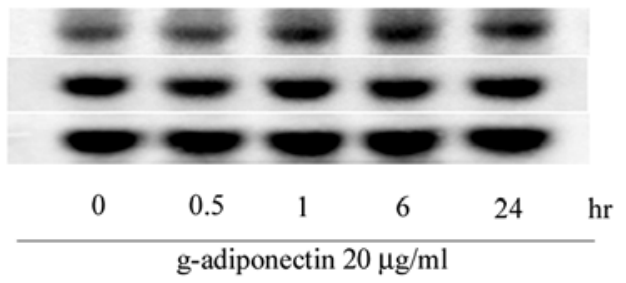

B

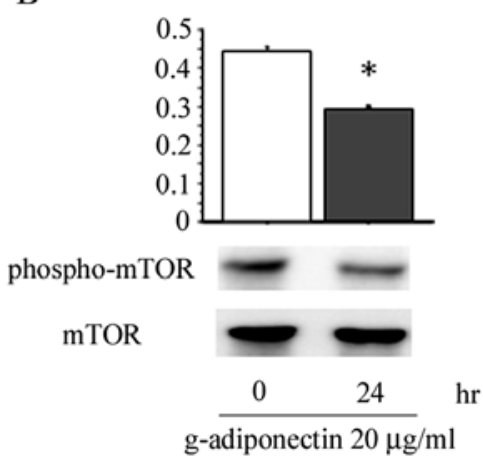

$\mathrm{C}$

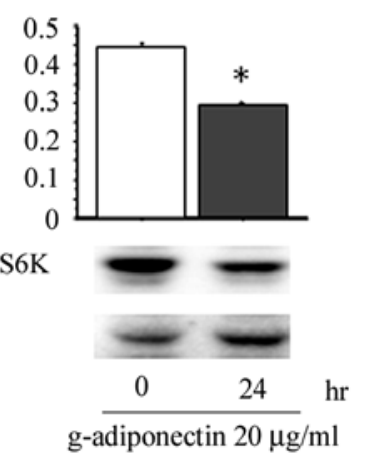

$\mathrm{D}$

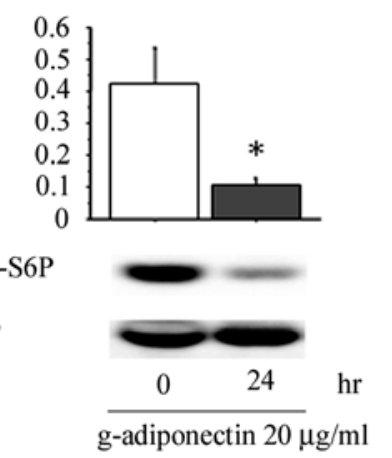

E

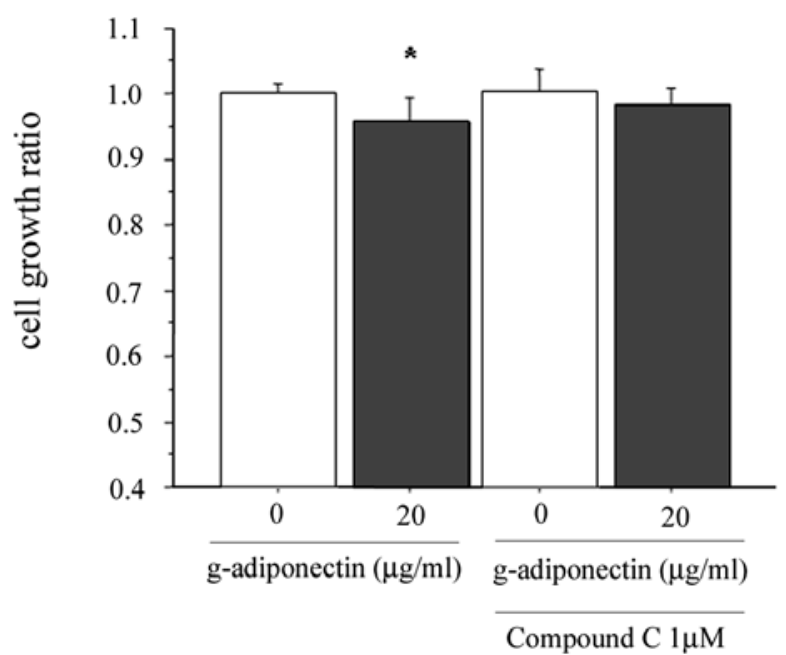

Figure 3. G-adiponectin up-regulates AMPK activity in colorectal cancer cell and selective AMPK inhibitor compound C reversed the g-adiponectin-induced cell growth. Western blot analysis was performed. HCT116 cells were treated with culture medium containing $1 \%$ FBS and g-adiponectin (20 $\mu$ g/ml) for $24 \mathrm{~h}$. After harvesting, cells were lysed and prepared for immunoblot analysis. (A) G-adiponectin increases AMPK phosphorylation and its effect on AMPK phosphorylation was maximal at $6 \mathrm{~h}$ after treatment. (B-D) G-adiponectin reduced phosphorylation of mTOR, p70S6K and S6P in HCT116 cells. Western blot analysis was performed in triplicate. Values are means \pm SEM. ${ }^{*} \mathrm{P}<0.05$. (E) To confirm the effect of adiponectin-induced growth inhibition via AMPK, HCT116 incubated in culture medium containing $1 \% \mathrm{FBS}$ and adiponectin $(20 \mu \mathrm{g} / \mathrm{ml})$ alone or with the addition of compound $\mathrm{C}$ ( $1 \mu \mathrm{M})$ for $24 \mathrm{~h}$ were used for MTT assay. Columns indicate means of four independent experiments carried out in triplicate ( $\mathrm{n}=8$ ); Values are means \pm SEM. ${ }^{*} \mathrm{P}<0.05$. 
A

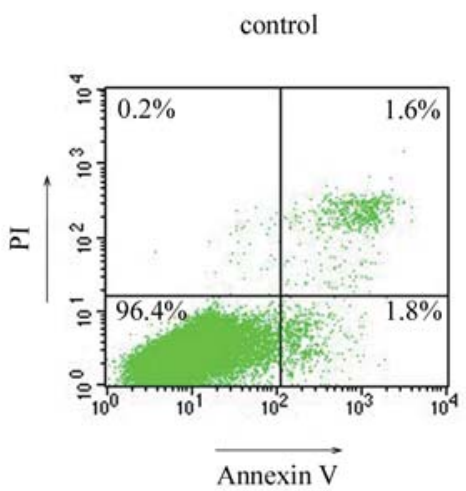

B

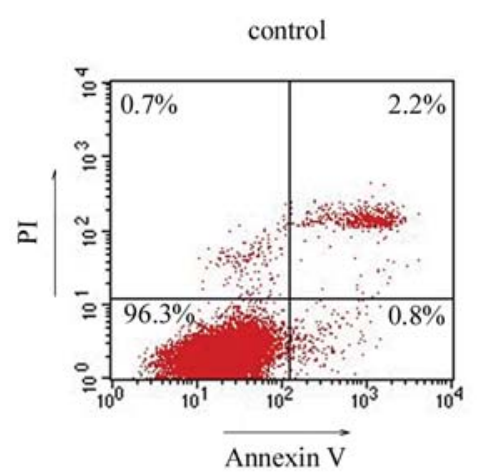

HCT116

g-adiponectin $5 \mu \mathrm{g} / \mathrm{ml}$

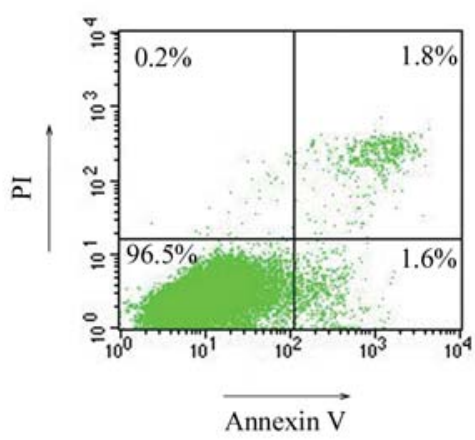

HT-29

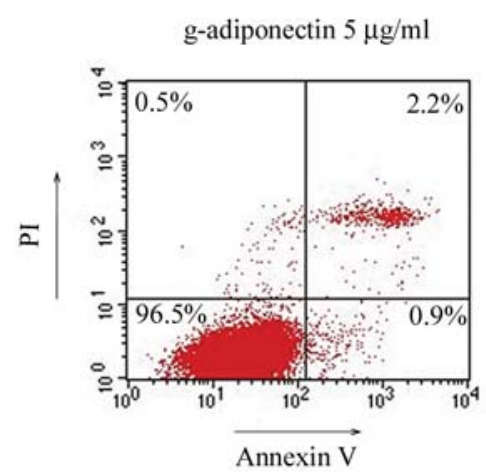

g-adiponectin $20 \mu \mathrm{g} / \mathrm{ml}$

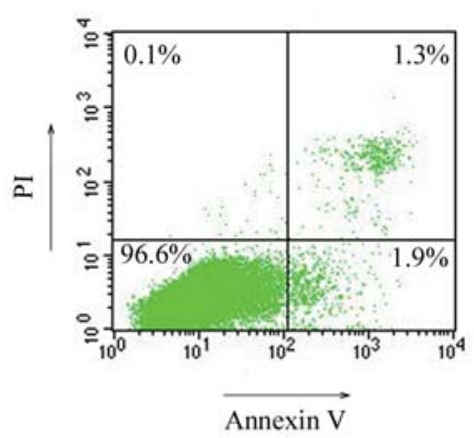

g-adiponectin $20 \mu \mathrm{g} / \mathrm{ml}$

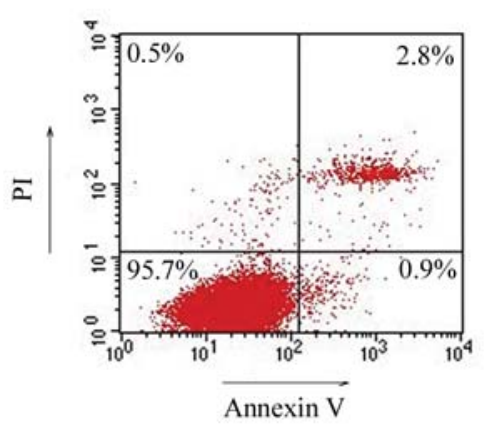

Figure 4. G-adiponectin has no effect on apoptosis. The apoptotic effect of g-adiponectin in HCT116 (A) and HT-29 (B) colorectal cancer cells incubated with culture medium containing $1 \% \mathrm{FBS}$ and g-adiponectin $(5 \mu \mathrm{g} / \mathrm{ml}$ or $20 \mu \mathrm{g} / \mathrm{ml})$ were evaluated via annexin V-FITC and PI double staining. Apoptosis measures were performed in triplicate.

growth through the activation of AMPK and subsequent suppression of mTOR pathway. This may be a key step in the elucidation of the effect of adiponectin on colorectal cancer. Further studies are required to elucidate the function of adiponectin in colorectal cancer.

\section{Acknowledgements}

We thank Machiko Hiraga and Yuko Sato for their technical assistance. This work was supported in part by a Grant-in-Aid for research on the Third Term Comprehensive Control Research for Cancer from the Ministry of Health, Labour and Welfare, Japan to A.N., a grant from the National Institute of Biomedical Innovation (NBIO) to A.N., a grant from the Ministry of Education, Culture, Sports, Science and Technology, Japan (KIBAN-B) to A.N, and a research grant from the Princess Takamatsu Cancer Research Fund to A.N.

\section{References}

1. Pischon T, Lahmann PH, Boeing H, Friedenreich C, Norat T, Tjønneland A, Halkjaer J, Overvad K, Clavel-Chapelon F, Boutron-Ruault MC, Guernec G, Bergmann MM, Linseisen J, Becker N, Trichopoulou A, Trichopoulos D, Sieri S, Palli D, Tumino R, Vineis P, Panico S, Peeters PH, Bueno-deMesquita HB, Boshuizen HC, van Guelpen B, Palmqvist R, Berglund G, Gonzalez CA, Dorronsoro M, Barricarte A, Navarro C, Martinez C, Quirós JR, Roddam A, Allen N, Bingham S, Khaw KT, Ferrari P, Kaaks R, Slimani N and Riboli E: Body size and risk of colon and rectal cancer in the European Prospective Investigation Into Cancer and Nutrition (EPIC). J Natl Cancer Inst 98: 920-931, 2006.
2. Takahash H, Yoneda K, Tomimoto A, Endo H, Fujisawa T, Iida H, Mawatari H, Nozaki Y, Ikeda T, Akiyama T, Yoneda M, Inamori M, Abe Y, Saito S, Nakajima A and Nakagama H: Life style-related diseases of the digestive system: colorectal cancer as a life style-related disease: from carcinogenesis to medical treatment. J Pharmacol Sci 105: 129-132, 2007.

3. Spranger J, Kroke A, Möhlig M, Bergmann MM, Ristow M, Boeing $\mathrm{H}$ and Pfeiffer AF: Adiponectin and protection against type 2 DM. Lancet 361: 226-228, 2003.

4. Hotta K, Funahashi T, Arita Y, Takahashi M, Matsuda M, Okamoto Y, Iwahashi H, Kuriyama H, Ouchi N, Maeda K, Nishida M, Kihara S, Sakai N, Nakajima T, Hasegawa K, Muraguchi M, Ohmoto Y, Nakamura T, Yamashita S, Hanafusa T and Matsuzawa Y: Plasma concentrations of a novel, adipose-specific protein, adiponectin, in type 2 diabetic patients. Arterioscler Thromb Vasc Biol 20: 1595-1599, 2000.

5. Yamauchi T, Kamon J, Waki H, Terauchi Y, Kubota N, Hara K, Mori Y, Ide T, Murakami K, Tsuboyama-Kasaoka N, Ezaki O, Akanuma Y, Gavrilova O, Vinson C, Reitman ML, Kagechika H, Shudo K, Yoda M, Nakano Y, Tobe K, Nagai R, Kimura S, Tomita M, Froguel $\mathrm{P}$ and Kadowaki T: The fat-derived hormone adiponectin reverses insulin resistance associated with both lipoatrophy and obesity. Nat Med 7: 941-946, 2001.

6. Berg AH, Combs TP, Du X, Brownlee M and Scherer PE: The adipocyte-secreted protein Acrp30 enhances hepatic insulin action. Nat Med 7: 947-953, 2001.

7. Kubota N, Terauchi Y, Yamauchi T, Kubota T, Moroi M, Matsui J, Eto K, Yamashita T, Kamon J, Satoh H, Yano W, Froguel P, Nagai R, Kimura S, Kadowaki T and Noda T: Disruption of adiponectin causes insulin resistance and neointimal formation. J Biol Chem 277: 25863-25866, 2002.

8. Maeda N, Shimomura I, Kishida K, Nishizawa H, Matsuda M, Nagaretani H, Furuyama N, Kondo H, Takahashi M, Arita Y, Komuro R, Ouchi N, Kihara S, Tochino Y, Okutomi K, Horie M, Takeda S, Aoyama T, Funahashi T and Matsuzawa Y: Dietinduced insulin resistance in mice lacking adiponectin/ACRP30. Nat Med 8: 731-737, 2002. 
9. Yamauchi T, Kamon J, Minokoshi Y, Ito Y, Waki H, Uchida S, Yamashita S, Noda M, Kita S, Ueki K, Eto K, Akanuma Y, Froguel P, Foufelle F, Ferre P, Carling D, Kimura S, Nagai R, Kahn BB and Kadowaki T: Adiponectin stimulates glucose utilization and fatty-acid oxidation by activating AMP-activated protein kinase. Nat Med 8: 1288-1295, 2002.

10. Tomas E, Tsao TS, Saha AK, Murrey HE, Zhang Cc C, Itani SI, Lodish HF and Ruderman NB: Enhanced muscle fat oxidation and glucose transport by ACRP30 globular domain: acetyl-CoA carboxylase inhibition and AMP-activated protein kinase activation. Proc Natl Acad Sci USA 99: 16309-16313, 2002.

11. Yamauchi T, Kamon J, Waki H, Imai Y, Shimozawa N, Hioki K, Uchida S, Ito Y, Takakuwa K, Matsui J, Takata M, Eto K, Terauchi Y, Komeda K, Tsunoda M, Murakami K, Ohnishi Y, Naitoh T, Yamamura K, Ueyama Y, Froguel P, Kimura S, Nagai R and Kadowaki T: Globular adiponectin protected ob/ob mice from diabetes and apoE deficient mice from atherosclerosis J Biol Chem 278: 2461-2468, 2003.

12. Tilg H and Hotamisligil GS: Non-alcoholic fatty liver disease: cytokine-adipokine interplay and regulation of insulin resistance. Gastroenterology 131: 934-945, 2006.

13. Hu E, Liang P and Spiegelman BM: AdipoQ is a novel adipose-specific gene dysregulated in obesity. J Biol Chem 271: 10697-10703, 1996.

14. Giovannucci E and Michaud D: The role of obesity and related metabolic disturbances in cancers of the colon, prostate, and pancreas. Gastroenterology 132: 2208-2225, 2007.

15. Wei EK, Giovannucci E, Fuchs CS, Willett WC and Mantzoros CS: Low plasma adiponectin levels and risk of CRC in men: a prospective study. J Natl Cancer Inst 97: 1688-1694, 2005.

16. Lukanova A, Söderberg S, Kaaks R, Jellum E and Stattin P: Serum adiponectin is not associated with risk of colorectal cancer. Cancer Epidemiol Biomarkers Prev 15: 401-402, 2006.

17. Yamauchi T, Kamon J, Ito Y, Tsuchida A, Yokomizo T, Kita S, Sugiyama T, Miyagishi M, Hara K, Tsunoda M, Murakami K, Ohteki T, Uchida S, Takekawa S, Waki H, Tsuno NH, Shibata Y, Terauchi Y, Froguel P, Tobe K, Koyasu S, Taira K, Kitamura T, Shimizu T, Nagai R and Kadowaki T: Cloning of adiponectin receptors that mediate antidiabetic metabolic effects. Nature 423: 762-769, 2003.

18. Goldstein BJ and Scalia R: Adiponectin: a novel adipokine linking adipocytes and vascular function. J Clin Endocrinol Metab 89: 2563-2568, 2004

19. Luo Z, Saha AK, Xiang X and Ruderman NB: AMPK, the metabolic syndrome and cancer. Trends Pharmacol Sci 26: 69-76, 2005

20. Long YC and Zierath JR: AMP-activated protein kinase signaling in metabolic regulation. J Clin Invest 116: 1776-1783, 2006.

21. Bolster DR, Crozier SJ, Kimball SR and Jefferson LS: AMPactivated protein kinase suppresses protein synthesis in rat skeletal muscle through downregulated mTOR signaling. J Biol Chem 277: 23977-23980, 2002.

22. Krause U, Bertrand L and Hue L: Control of p70 ribosomal protein S6 kinase and acetyl-CoA carboxylase by AMP-activated protein kinase and protein phosphatases in isolated hepatocytes. Eur J Biochem 269: 3751-3759, 2002.

23. Vogt PK: PI 3-kinase, mTOR, protein synthesis and cancer. Trends Mol Med 7: 482-484, 2001

24. Valentinis B and Baserga R: IGF-I receptor signalling in transformation and differentiation. Mol Pathol 54: 133-137, 2001

25. Oldham S and Hafen E: Insulin/IGF and target of rapamycin signaling: a TOR de force in growth control. Trends Cell Biol 13: 79-85, 2003.
26. Jacinto $\mathrm{E}$ and Hall MN: Tor signalling in bugs, brain and brawn Nat Rev Mol Cell Biol 4: 117-126, 2003.

27. Dancey JE: Clinical development of mammalian target of rapamycin inhibitors. Hematol Oncol Clin North Am 16: 1101-1114, 2002.

28. Huang S and Houghton PJ: Targeting mTOR signaling for cancer therapy. Curr Opin Pharmacol 3: 371-377, 2003.

29. Philp AJ, Campbell IG, Leet C, Vincan E, Rockman SP, Whitehead RH, Thomas RJ and Phillips WA: The phosphatidylinositol 3'-kinase p85alpha gene is an oncogene in human ovarian and colon tumors. Cancer Res 61: 7426-7429, 2001.

30. Fingar DC, Richardson CJ, Tee AR, Cheatham L, Tsou C and Blenis J: mTOR controls cell cycle progression through its cell growth effectors S6K1 and 4E-BP1/eukaryotic translation initiation factor 4E. Mol Cell Biol 24: 200-216, 2004.

31. Hardie DG: New roles for the LKB1 $\rightarrow$ AMPK pathway. Curr Opin Cell Biol 17: 167-173, 2005.

32. Mantzoros C, Petridou E, Dessypris N, Chavelas C, Dalamaga M, Alexe DM, Papadiamantis Y, Markopoulos C, Spanos E, Chrousos G and Trichopoulos D: Adiponectin and breast cancer risk. J Clin Endocrinol Metab 89: 1102-1107, 2004.

33. Miyoshi Y, Funahashi T, Kihara S, Taguchi T, Tamaki Y, Matsuzawa Y and Noguchi S: Association of serum adiponectin levels with breast cancer risk. Clin Cancer Res 9: 5699-5704, 2003.

34. Petridou E, Mantzoros C, Dessypris N, Koukoulomatis P, Addy C, Voulgaris Z, Chrousos G and Trichopoulos D: A casecontrol study in Greece. J Clin Endocrinol Metab 88: 993-997, 2003.

35. Petridou E, Mantzoros C, Dessypris N, Koukoulomatis P, Addy C, Voulgaris Z, Chrousos G and Trichopoulos D: Circulating adiponectin and endometrial cancer risk. J Clin Endocrinol Metab 89: 1160-1163, 2004.

36. Otake S, Takeda H, Suzuki Y, Fukui T, Watanabe S, Ishihama K, Saito T, Togashi H, Nakamura T, Matsuzawa Y and Kawata S: Association of visceral fat accumulation and plasma adiponectin with colorectal adenoma: evidence for participation of insulin resistance. Clin Cancer Res 11: 3642-3646, 2005.

37. Yoneda K, Tomimoto A, Endo H, Iida H, Sugiyama M, Takahashi H, Mawatari H, Nozaki Y, Fujita K, Yoneda M, Inamori M, Nakajima N, Wada K, Nagashima Y, Nakagama H, Uozaki H, Fukayama M and Nakajima A: Expression of adiponectin receptors, AdipoR1 and AdipoR2, in normal colon epithelium and colon cancer tissue. Oncol Rep 20: 479-483, 2008.

38. Schmelzle T and Hall MN: TOR, a central controller of cell growth. Cell 103: 253-262, 2000.

39. Panwalkar A, Verstovsek S and Giles FJ: Mammalian target of rapamycin inhibition as therapy for hematologic malignancies. Cancer 101: 1478, 2004

40. De Young MP, Horak P, Sofer A, Sgroi D and Ellisen LW: Hypoxia regulates TSC $1 / 2$-mTOR signaling and tumor suppression through REDD1-mediated 14-3-3 shuttling. Genes Dev 15: 239-251,2008.

41. McCubrey JA, Steelman LS, Abrams SL, Bertrand FE, Ludwig DE, Bäsecke J, Libra M, Stivala F, Milella M, Tafuri A, Lunghi P, Bonati A and Martelli AM: Targeting survival cascades induced by activation of Ras/Raf/MEK/ERK, PI3K/ PTEN/Akt/mTOR and Jak/STAT pathways for effective leukemia therapy. Leukemia 22: 708-722, 2008. 